\title{
胃全摘後空腸 pouch 再建の有用性
}

\author{
き医師会病院外科 \\ 足立 信也 河島 孝彦 石川智義 尾崎 梓
}

胃全摘術後患者の愁訴の大部分をしめる胸やけ，食事摄取量の不足，体重減少を解決する目的で空 腸囊を用いた pouch-Y 吻合法を12例に施行した.従来の $\rho$-Roux-Y 吻合法を施行した15例を対照とし て, 術後の愁訴, 食事摄取量, 体重の変動, 赤血球数, total protein (TP), albumin (ALB), cholesterol (CHO), triglyceride (TG) の変化を比較検討した。その結果, pouch-Y 法では対照群に比べて胸や け，動悸や下痢が少なく，1回食事量が多く，術後の体重の回復が有意に良好であった．赤血球数， TP, ALB, CHO, TG の諸検查值には有意差がなかった。経過観察期間は術後18か月であり, 術後早 期において pouch-Y 法は栄養学的に，また患者の quality of life においても満足できる再建法である ことが確認された。

Key words : reconstruction after total gastric resection, jejunal pouch, small gastric syndrome

\section{はじめに}

胃全摘術後の患者の愁訴には胸やけ，食物のつかえ 感, 動悸, 腸鳴, 下痢などの主として逆流性食道炎や ダンピング症候群といった合併症に起因するもののほ かに, 1 回の食事拱取量が少ない, 間食が必要である というような健康時と異なった食生活を余儀なくされ ていることに対する不満があげられる1.これらの不 満から患者は体調がよくないと感じ，体調がよくない と感じている患者の職場復帰は困難になっている2).

われわれは胃全摘後の再建術式に $\rho$-Roux-Y吻合 法の $\rho$-loop を自動縫合器 (GIA) を用いて空腸囊にす る方法（以下, pouch-Y 法と略記）を取り入れ，代用 胃の貯留能を高め, 食事摄取量を増加させる試みを 行っている.

本報告では pouch-Y 法の術後患者の愁訴, 栄養学的 指標として血液諸検查値, 体重を経過観察し,これら を従来の $\rho$-Roux-Y 吻合法の術後患者と比較して報 告する.

手術術式 (Pouch-Y 法)

1) 食道切離後, 食道に巾着縫合をかけ, EEA(PREMIUM CEEA, USSC) の anvil を縫着した.

2) 胃切除後, Treitz 䨣帯から $30 \mathrm{~cm}$ 肛門側の空腸を 切離した後, 結腸前に空腸を挙上し, $20 \mathrm{~cm} の 100 \mathrm{p}$

$<1994$ 年 5 月 11 日受理 $>$ 別刷請求先：足立 信也 厂305 つくば市天王台 $1-1-1$ 筑波大学臨床医 学系外科
つくり，両端に支持系を置いた。

3）肛門側空腸の腸間膜反対側に $2 \mathrm{~cm}$ の繸切開をい れ、ここから GIA 80 (MULTIFIRE GIA, USSC) を 2 回挿入, 器械縫合し, pouch を作製した。獎膜縫 合は追加しなかった.

4）EEA を挿入し，食道-pouch 吻合を行った.

5）pouch の閉鎖は staple のかかっている中央部分 から始め, 口側空腸の断端と肛門側空腸の切開部をそ れぞれ Albert-Lembert 縫合して行った.

6）食道-pouch 吻合から $40 \mathrm{~cm}$ 離して空腸空腸端側 吻合を行った (Fig. 1).

\section{対象ならびに方法}

\section{1. 対象}

術後 6 か月以上経過した pouch-Y 群12例と, RouxY 群15例を対象とし, 術後18か月まで追跡した。

1) pouch-Y 群

1992年 1 月から1993年 5 月まで12例に pouch-Y 法 を行った。全例胃癌症例で年齢は35歳から77歳, 女性 が1例でほかはすべて男性であった。胃癌の進行度は stage 1 が 2 例, stage 3 が 6 例, stage 4 が 4 例であっ た，1例に R1，11例に R2郭清を行い，4例に脾合併 切除を， 7 例に脾膵尾部合併切除を行った。症例 3 に は左開胸を加えた (Table 1). 術後の治療として case 1，6，12は抗癌剤投与を行わず， case 2，4，5は経口 抗癌剤単独, case 3 は経口抗癌剤十放射線治療, case $7 ， 9 ， 11$ は経口抗癌剂 + mitomycin C (以下, MMC と 略記) の間欠的静注, case 8,10は経口抗癌剂 + meth- 
Fig. 1 Pouch- $Y$ reconstruction

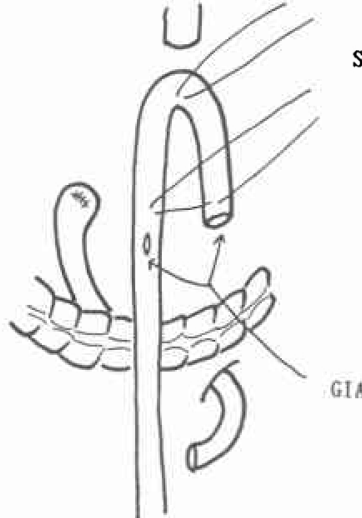

Step 1

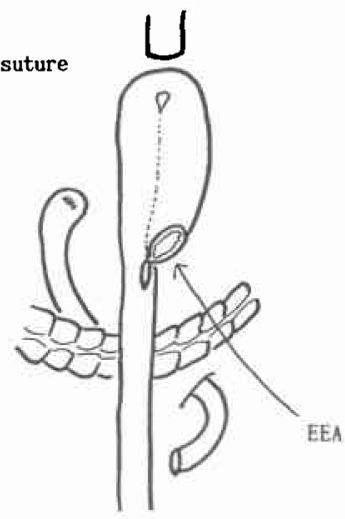

Step 2
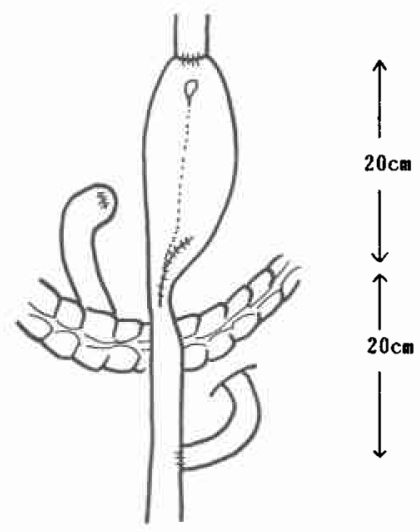

Step 3
Table 1 Profiles of the patients underwent pouch$\mathrm{Y}$ reconstruction

\begin{tabular}{r|c|c|c|c|c}
\hline Case & Age & Sex & Stage & $\begin{array}{c}\text { Resecta- } \\
\text { bility }\end{array}$ & Outcome \\
\hline 1 & 77 & M & se n2 p0, 3 & R2, PS* & dead (5mo) \\
2 & 60 & M & ss n2 p0, 3 & R2, PS* & alive(18mo) \\
3 & 59 & M & se n2 p0, 3 & R2, PS* & alive(18mo) \\
4 & 66 & M & se n2 p1, 4 & R2, PS* & alive(15mo) \\
5 & 76 & M & se n2 p0, 3 & R2, PS* & alive(15mo) \\
6 & 39 & M & sm n0 p0, 1 & R2, S** & alive(15mo) \\
7 & 75 & M & se n2 p2, 4 & R2, S** & alive(15mo) \\
8 & 35 & F & se n2 p2, 4 & R2, S** & alive(12mo) \\
9 & 44 & M & se n2 p0,3 & R2, PS* & alive(9mo) \\
10 & 53 & M & se n2 p3, 4 & R1 & alive(9mo) \\
11 & 63 & M & se n2 p0,3 & R2, PS* & alive(6mo) \\
12 & 74 & M & m n0 p0, 1 & R2, S** & alive(6mo) \\
\hline
\end{tabular}

* : with caudal pancreatectomy and splenectomy

**: with splenectomy

\section{otrexate $(\mathrm{MTX}) / 5 \mathrm{FU}$ 交代療法を行った。}

\section{2) Roux-Y 群}

1988年から1992年 6 月までに $\rho$-Roux-Y吻合法を 行った15例を対象とした。全例胃癌症例で年歯は 49 歳 から 83 歳, 女性が 8 例で男性が 7 例であった。胃癌の 進行度は stage 1 が 2 例, stage 2 が 1 例, stage 3 が 12 例であった． 3 例に R1，2例に R2郭清を行い，4 例に 脾合併切除を， 8 例に脾膵尾部合併切除を行った (Table 2). 術後の治療として, case 6，7，8，15は抗 癌阂投与を行わず， case 1, 2, 5, 9, 10, 12, 13, 14 は経口抗癌剂単独, case 3, 4, 11は経口抗癌剤 + MMC
Table 2 Profiles of the patients underwent Roux-Y reconstruction

\begin{tabular}{r|c|c|c|c|c}
\hline Case & Age & Sex & Stage & $\begin{array}{c}\text { Resecta- } \\
\text { bility }\end{array}$ & Outcome \\
\hline 1 & 55 & F & se n2 p0,3 & R2, PS* & alive(18mo) \\
2 & 49 & F & se n2 p0,3 & R2, PS* & alive(18mo) \\
3 & 56 & M & se n2 p0,3 & R2, PS* & alive(18mo) \\
4 & 67 & M & se n2 p0,3 & R2, PS* & alive(18mo) \\
5 & 66 & M & se n0 p0,3 & R2, PS* & alive(15mo) \\
6 & 77 & F & se n2 p0,3 & R2, S** & alive(18mo) \\
7 & 64 & M & m n0 p0, 1 & R2, S** & alive(18mo) \\
8 & 83 & M & se n0 p0,3 & R1 & dead(13mo) \\
9 & 75 & F & se n1 p0,3 & R2, S** & alive(18mo) \\
10 & 64 & F & se n0 p0,3 & R2, PS* & alive(18mo) \\
11 & 69 & F & se n2 p0,3 & R2, S** & dead (15mo) \\
12 & 66 & F & se n2 p0,3 & R2, PS* & alive(18mo) \\
13 & 55 & M & se n2 p0,3 & R2, PS* & alive(18mo) \\
14 & 72 & F & pm n1 p0,2 & R1 & alive(18mo) \\
15 & 60 & M & m n0 p0, 1 & R1 & alive(18mo) \\
\hline
\end{tabular}

* : with caudal pancreatectomy and splenectomy

** : with splenectomy

の間欠的静注を行った。

\section{2. 方法}

患者自身への質問は,

1）胸やけや動悸，下痢症状はないか

2）健康時と比べて現在の食事摂取量は何割程度か, の 2 点である.

他覚所見として各時期における体重 (BW), 赤血球 数 (以下, $\mathrm{RBC}$ ), 総蛋白質 (以下, $\mathrm{TP}$ ), 血清アルブ 
ミン(以下, ALB), 総コレステロール(以下, $\mathrm{CHO}$ ), 中性脂肪（以下, TG）を測定し, 両群間で比較した. まず $\mathrm{F}$ 検定を行い, 分散が等しいと仮定された後, $\mathrm{t}$ 検 定を用いて有差意検定を行った。

\section{成 績}

両群の胃全摘膵尾部脾合併切除術の平均手術時間は 同一術者で pouch-Y 群が 3 時間17分, Roux-Y 群が 3 時間21分であった. 全例術後 1 週間で経口攝取を再開 した。経過観察中に転移, 再発と診断された症例はそ れ以降のデータを除外した, pouch-Y 群では症例 1 が 5 か月で腹膜再発, Roux-Y 群では症例 8 が13か月で 死亡, 症例 9 が 1 年で, 症例 11 が 9 か月でそれぞれ腹 膜再発と診断された。なお，組織学的に絶対非治癒切 除となった pouch-Y 群の症例 $7,8,10$ はいずれも腹 膜転移症例であるが画像診断上, 現時点で癌病巣はと らえられていない。

1. 胸やけを訴えた症例は pouch-Y 群で術後 6 か 月, 9 か月で各 1 例, Roux-Y 群では術後 1 か月で 1 例, 2 か月で 2 例, 3 か月で 3 例, 9 か月で 3 例であっ た. 発汗，動悸，下痢などのダンピング症状を訴えた 症例は pouch-Y 群にはなく, Roux-Y 群にのみ術後 1 年で 2 例, 18 か月で 1 例あった。

2. 健康時と同程度, またはそれ以上の食事摂取量で あると答えた症例は pouch-Y 群で全例, Roux-Y 群で は 5 例であった。その時期は pouch-Y 群で術後 1 か月 が 3 例, 2 か月が 1 例, 3 か月が 3 例, 6 か月が 3 例, 9 か月が 2 例であった. Roux-Y 群では術後 3 か月が 2 例， 6 か月が 2 例， 1 年が 1 例であった (Fig. 2).

\section{3. 体重の変動}

Fig. 2 Heart burn, dumping, and intake in the postoperative period

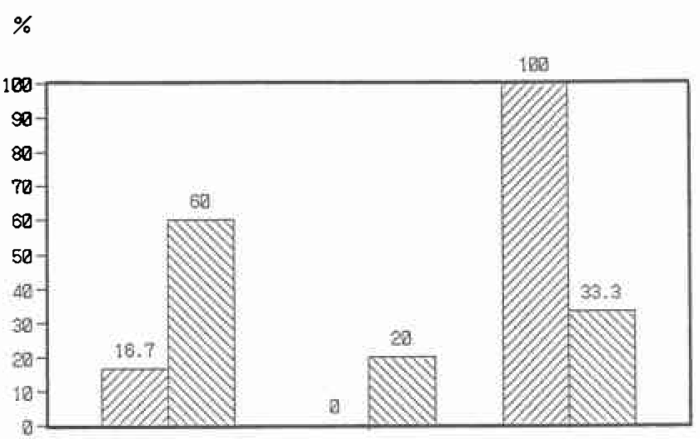

Heart burn Dumping Intake $\square$ pouch-Y group $\$$ Roux-Y group
Fig. 3 Body weight change

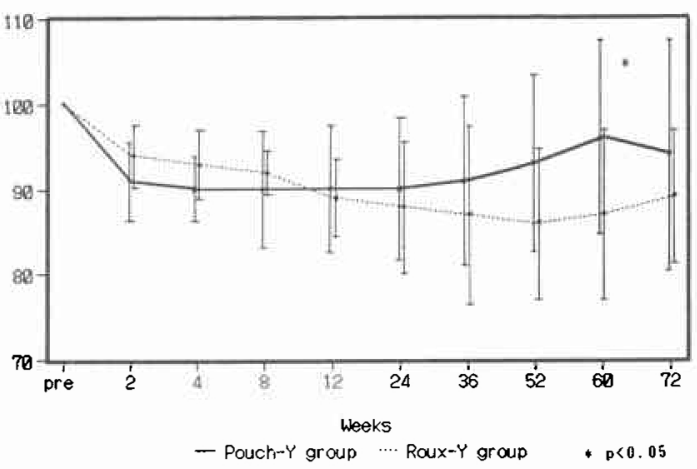

Fig. 4 Changes of red blood cell counts

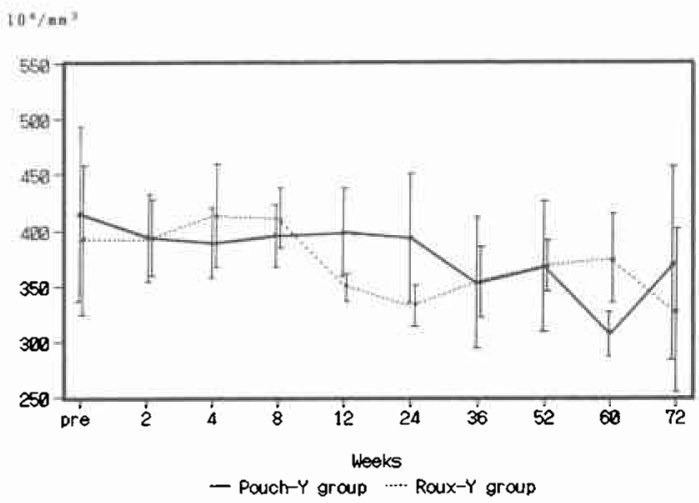

両群とも全例, 術後 1 週で経口攝取を開始した. 術 前の体重は pouch-Y 群が54.3土9.6kg, Roux-Y 群が $51.5 \pm 8.3 \mathrm{~kg}$ と差がなかった. 術前の体重を基準とし て各時期の体重の割合の変動をみた. Pouch-Y 群では 術後 3 か月から次第に体重が増加し, 術後15か月では $96.0 \pm 10.0 \%$ あった. Roux-Y 群では術後 1 年まで 漸減し,その後増加した。術後18か月では88.5土11.8\% であった。術前值を上まわった症例は pouch-Y 群では 12例中 4 例, Roux-Y 群では15例中 2 例であった.衍後 15か月の両群間の体重の割合には危険率 $5 \%$ 以下で有 意差が認められた（Fig. 3)。

\section{4. 赤血球数の変動}

術前值は pouch-Y 群 $414 \pm 7410^{4} / \mathrm{mm}^{3}$, Roux-Y 群 $392 \pm 7110^{4} / \mathrm{mm}^{3}$ と差が認められなかった. 術後も各 時期で両群間に有意差は認められなかった(Fig. 4).

\section{5. 血清総蛋白質の変動}

術前值 は pouch-Y 群 $6.4 \pm 0.6 \mathrm{~g} / \mathrm{dl}$, Roux-Y 群 $6.4 \pm 0.8 \mathrm{~g} / \mathrm{dl}$ であった. 術後の各時期も両群間に有意 
Fig. 5 Changes of serum total protein values

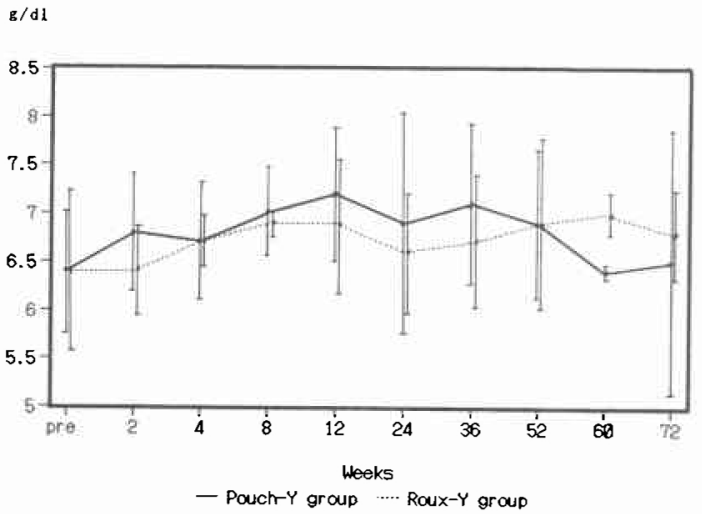

Fig. 6 Changes of serum albumin values $\mathrm{g} / \mathrm{d} 1$

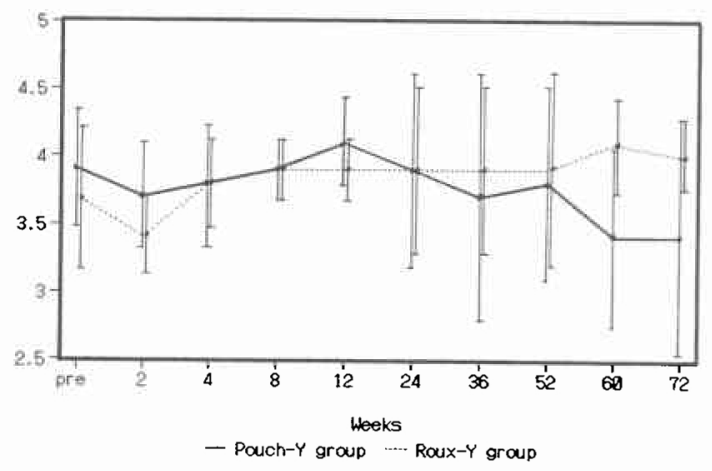

Fig. 7 Changes of serum cholesterol values $\operatorname{mg} / \mathrm{d} 1$

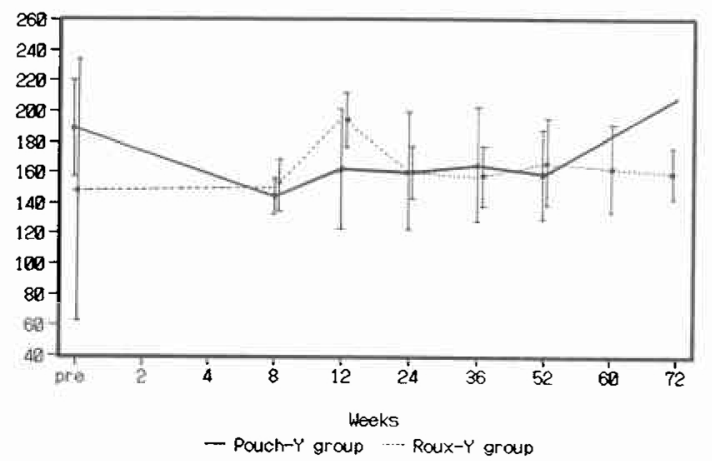

差は認められなかった，手術直後をのぞき，正常範囲 内であった (Fig. 5).

6. 血清アルブミン值の変動

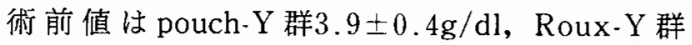
$3.7 \pm 0.5 \mathrm{~g} / \mathrm{dl}$ であった。術後も両群間に有意差は認め
Fig. 8 Changes of serum triglyceride values

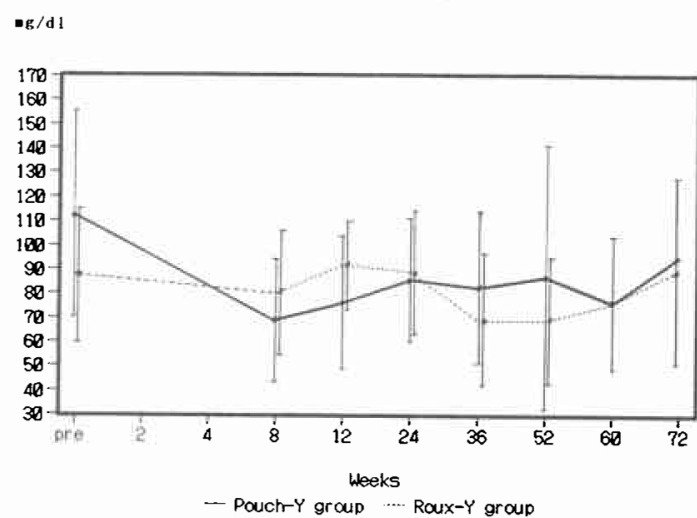

られなかった（Fig. 6).

7. 総コレステロール值の変動

術前值は pouch-Y 群174 $146 \mathrm{mg} / \mathrm{dl}$, Roux-Y 群 $144 \pm 89 \mathrm{mg} / \mathrm{dl}$ と差がみられなかった。術後の各時期 も両群間に有意差は認められず，正常範囲内であった (Fig. 7).

8. 中性脂肪の変動

術前值 は pouch-Y 群 $112 \pm 43 \mathrm{mg} / \mathrm{dl}$, Roux-Y 群 $88 \pm 27 \mathrm{mg} / \mathrm{dl}$ であった. 術前, 術後とも両群間で有意 差はみられず，正常範冊内であった（Fig. 8).

\section{考察}

胃全摘後の再建術式の評価をするには，胃が切除さ れたことによる無酸状態, ペプシンの消失といった必 然的に生じる変化を除外して栄養学的に満足できるも のであるかどうか，患者の quality of life(以下，QOL と略記）は良好であるかどうかの検討が重要である. 術後患者の QOL を評価する方法は非常に困難で, 患 者自身の精神的成熟度によるという説もある ${ }^{3)}$. しか し, 愁訴が少なく体調がよいと感じることにより，術 後の QOL が向上することは間違いない.

今回われわれは栄養学的な評価の指標として RBC, TP, ALB， CHO，TGをそれぞれ測定した. 各検査值とも術前術後を通じてほとんど変化がなく, 両群間に有意差はみられなかった。したがって血液 データから両群間の術後の栄養学的な変化を指摘する ことはできなかった。

胃全摘後の体重減少については消化吸収障害と食事 摂取量の不足が大きな要因である ${ }^{4)}$. 消化吸取障害に ついて, 井口ら ${ }^{5} は$ 炭水化物の消化吸収はほとんど障 害されないが蛋白質，とくに脂肪はあきらかに障害さ れるとしている，再建術式別に検討した報告では，百 
瀬到は蛋白質と脂肪の消化吸収は空腸間置術よりも Roux-Y 吻合法のほうが不良であるとし,長見ら》は膵 内分泌機能に扔いても空腸間置術のほうが有効である としている．しかしながら Fischermann ら゙は脂肪の 吸収において両術式に差はないとし, Winchester ら ${ }^{9)}$ は消化吸収障害よりも食事掑取量の差が術後の体重減 少の主因であるとした。

食物の貯留能を高めるために二重腸管を用いる試み は古くからなされている，空腸を長く利用するよりも 二重腸管のほうが容積は 2 倍になり, 食餌の貯留能は 堌加する ${ }^{10)}$. Scott $ら^{11)}$ は Hunt Lawrence Pouch を作 製してY吻合し，従来の Roux-Y 吻合と比較検討し た。その結果, 1 回摄取食事量は増加し, 体重減少が 少なかったとしている。これに対して Auguste ら ${ }^{12}$ は 両術式にはまったく有意差がなかったとし，Troidl $ら^{13}$ は Hunt Lawrence Pouchのほうが体重変動や QOL の面から優れているとしながらも,手技が繁雑で 時間がかかり，患者への侵襲は大きくなると結論した。 しかし, Thiede ら ${ }^{14)}$ は器械吻合を用いることにより, 手縫い方法よりも手術時間は約 1 時間短くなると報告 した。われわれの手術時間には両群間でほとんど差が なく，手技が煩雑であるということはない.

今回の我々の報告では消化吸収機能について検討を 加えていないが栄責学的な評価の指標とした. RBC, TP, ALB, CHO, TG の名時点における測定值には有 意差がみられず, 正常箶囲内の変動であった。諸家の 報告でも術式により消化吸収試験の結果に差が認めら れても TP, ALB, CHO, RBC などの諸検査値に差は 認められていない(111)15). 両群とも食事により, 必須の 栄養素の吸収は十分であると考えられた。患者の自己 申告による食事摄取量では pouch-Y 群の12例全例が 健康時と同程度またはそれ以上の食事掑取量であると 答え, Roux-Y 群では同様の答えは 15 例中 5 例のみで あったことから, pouch-Y法により胃全摘後患者の捸 取能は有意に改善されたと判断された. 攝取カロリー の検討は行っていないが pouch-Y 群における術後の 良好な体重の回復は食事摂取量の差によると考えられ た.さらに胸やけやダンピング症状があきらかに少な く, 術後患者の QOL は良好であった. 胸やけやダンピ ング症状が減少した理由として以下のように考えてい る.

pouch-Y 法, $\rho$-Roux-Y 法とも食道空腸吻合から空 腸空腸端側吻合までの距離は $40 \mathrm{~cm}$ であるが $\rho$-RouxY 法の吻合, 口側空腸が食道へ向かって順蠕動である
ため, 空腸内容が食道へ流入しやすいのに対し, pouch-Y 法では術後造影で見る限り, pouch 内は順蠕 動と逆蠕動が混在したような動きをし, 緩やかに肛門 側へ流れ，食道に流入しなかった。このため胸やけが 減少したと考元られた。さらに pouch 閉鎖する際, 肛門側空腸においた綐切開を Albert-Lembert 縫合す るため, 約 $2 \mathrm{~cm}$ ほどの狭窄部分を生じる. Pouch 内の 順蠕動と逆蠕動の混在と pouch 出口の狭窄により食 物は停滞し,肚門側小腸へ急激に流入することがなく, 腸鳴，下痢などのダンピング症状が減少したと考えら れた.

胃全摘後患者の QOLについて多くの報告がなされ ているが, 岩永ら は) QOL を決定する最大因子は患者 自身の精神的成熟度であり，他人が判定することは不 そんであると述べている，したがって外科医ができう る手技の改善は愁訴の少ない再建法を用いることであ る. 胃全摘後の愁訴をアンケートにより集計した報告 によると 1 回の食事摂取量が多く, 体重減少があまり なく, 胸やけ，動悸や下痢がないことが生活の質を向 上させ，ひいては社会復帰を容易にしている(15 17). 本 研究では胃全摘術において空腸 pouchを用いた再建 術式では, 従来の Roux-Y 吻合に比べて術後早期から 胸やけが少なく，1回食事拱取量が多く，いったん隇 少した体重の増加が良好なことが確認された. Buhl ら ${ }^{18)}$ は Hunt Lawrwnce pouch による再建は幽門側胃 切除術に匹敵する良好な術後QOLをもたらすとして いる. 今後は症例を重ね, 術後長期の検討, とくに消 化吸収機能に及ぼす影響について検討を加えたい. ま た, pouch-Y 吻合術と pouch interposition 吻合術を比 較検討した研究も現在実施中である.

本論文の要旨は第 42 回日本消化器外科学会総会ビデオ セッションにおいて発表した。

\section{文 献}

1）日置紘士郎，中根恭司，岡本真司ほか：小胃症状・ るいそう。外科診療 $31: 1131-1138,1989$

2）大柳治正, 野木佳男, 関田幹雄ほ加: 胃癌胃切除に 対する再建術式の検討。手術 32：1363-1371， 1978

3) 岩永 剛, 古河 洋, 平塚正弘ほか: Quality of life 汃らた進行性胃癌に対する抎大手術の評 価. 日消外会誌 $23 ： 959-962 ， 1990$

4）朴 常秀, 山本政勝, 中根恭司: 術後遠隔期の栄養 障害・胃疾患. 栄評治 8:33-40, 1991

5）井口 潔, 友田博次: 胃切除後 Malabsorption. 臨 外 $30: 523-527,1975$

6）百瀬隆二：胃全摘術後長期経過例における骨代謝 
障害, 消化吸収障害ならびに貧血に関する検討.日 消外会誌 $24: 779-787,1991$

7）長見晴彦, 田村勝洋, 金 聲根ほか：再建術式より みた胃全摘後病態の臨床的検討. 日臨外医会誌 $51: 1649-1654,1990$

8) Fischermann $\mathrm{K}$, Harly $\mathrm{S}$, Worning $\mathrm{H}$ et al : Pancreatic function and the absorption of fat, iron, citamin B12, and calcium after total gastrectomy for gastric carcinoma. Gut 8 : 260-266, 1967

9) Winchester DP, Randolph DA, Dorsey JM et al : The role of rapid intestinal transit in postgas. trectomy malnutrition. Surg Gynecol Obstet $132: 861-865,1971$

10）近藤達平, 立松 輝, 岡田恒良ほか：胃全摘除後の 小晹間置術式による再建. 消外 $13: 1189-1199$, 1990

11) Scott HW, Law DH, Dobbel WG et al: Clinical and metabolic studies after total gastrectomy with a Hunt-Lawrence jejunal food pouch. Am J Surg 115 : 148-156, 1968

12) Auguste LJ, Mavor E, Citrin P et al: Nutri- tional effects of postgastrectomy reconstructions. Am J Surg 150:537-542, 1985

13) Troidl H, Kusche J, Vestweber $\mathrm{KH}$ et al : Pouch versus esophagojejunostomy after total gastrectomy: a randomized clini cal trial. World J Surg 11:699-712, 1987

14) Thiede A, Fuchs KH, Hamelman H: Pouch and Roux-en-Y reconstruction after gastrectomy. Arch Surg $112: 837-842,1987$

15）坂本孝作：胃全摘後 long loop Roux $Y$ 一層縫合 再建術式の総合評価. 日臨外医会誌 46 : $1221-1231,1985$

16）小玉雅志, 小山裕文, 曽根純之ほか: 胃癌手術後の Quality of life. 日臨外医会誌 $51: 466-471$, 1990

17）宮本幸男, 大和田進, 棚橋美文ほか：Quality of lifeよりみた胃全摘再建法の検討. 北関東医 41:735-741, 1991

18) Buhl K, Schlag P, Herfarth C: Quality of life and functional results following different types of resection for gastric carcinoma. Eur J Surg Oncol 16:404-409, 1990

\section{Usefullness of Jejunal Pouch Reconstruction After Total Gastrectomy}

\section{Shinya Adachi, Takahiko Kawashima, Tomoyoshi Ishikawa and Azusa Ozaki} Department of Surgery, Kinu Medical Association Hospital

In order to resolve major complaints after total gastric resection, e.g., heartburn, reduction of food capacity and body weight loss, we performed jejunal pouch-Y reconstruction with GIA in 12 patients with gastric carcinoma. We compared this pouch group with a $\rho$-Roux-Y reconstruction group as to body weight change, red blood cell count and concentrations of TP, ALB, CHO and TG. We also asked the patients about their postoperative symptoms and effects on nutrition. The patients in the pouch group had greater eating capacity, less heart burn and faster recovery of body weight than those of the Roux-Y group. There were no significant differences in red blood cell count, TP, ALB, CHO and TG. These results suggested that jejunal pouch- $Y$ reconstruction after total gastric resection can be recommended from the standpoint of quality of life.

Reprint requests: Shinya Adachi Department of Surgery Institute of Clinical Medicine University of Tsukba 1-1-1, Tennoudai, Tsukuba, 305 JAPAN 